\title{
LAND DEVELOPMENT POSSIBILITIES IN SOUTHLAND
}

\author{
G. J. WATT, Commissioner of Crown Lands, Invercargill
}

An eminent writer has said "Opinions must be judged like coins, by their metal and not by their superscription." If therefore the title of this address appears presumptuous to you, as it certainly does to me, let us pass it by and concentrate on the metal, in the hope that it will in some measure bear scrutiny.

I shall deal first with my estimate of Southland's farming potential during the next 20 years and then suggest how, by a combination of State and private enterprise, that potential can be realised.

The_Southland_Land_District,_including_the_two_scenic_gems_of Fiordland and Stewart Island, contains 8,260,171 acres, but in this paper attention will be confined to the occupied area of some $3,700,000$ acres, there being but very limited areas of unoccupied Crown land capable of economic development during the period under review.

\section{Southland's Potential}

Let us look at the potential of these 3.7 million acres.

To the casual visitor Southland epitomises highly fertile farms, attractive homesteads, and an air of solidarity and prosperity. And, as is well known, the best "Canterbury" fat lamb comes from Southland! But there is still considerable potential. My approach has been to begin in 1960, take stock in 1970, and continue until 1980.

In seeking to arrive at the overall potential, I shall deal with the occupied land in four classes: undeveloped, partially developed, pastoral, and developed. For the basic material I have relied on the assiduous efforts of Field Officer J. J. Wallace; Pastoral Lands Officer A. R. Aitken has supplied the figures on the pastoral areas.

\section{Class l-Undeveloped Land-I 50,000 Acres}

Reference to the accompanying map will show that the major areas of undeveloped land lie in the Upper Waiau, Rowallan, Hokonui, and the Seaward Moss districts. Nearly half of the area is in partly milled bush, the balance being in tussock and swamp, and development on the whole will bc slow and costly. Its present capacity is placed at 4,500 sheep and 200 run cattle, the res- 
pective figures in 1970 being 22,000 sheep, 1,100 run cattle, and 200 dairy cattle. In 1980 the barometer reads 92,300 sheep, 3,400 cattle, and 400 dairy cattle. The grassed area in 1980 is shown at 46,000 acres and it is expected that the Crown will make a considerable impact on development, particularly during the sccond decade.

\section{Class 2-Partially Developed Land--644,500 Acres}

For clarity I have included here the areas held by the Department of Lands and Survey-40,000 acres of grass carrying 60,000 sheep and 6,500 run cattle. Until equilibrium is reached between areas grassed and areas settled, these stock numbers will increase somewhat. The balance of the land is mainly found in Waiau, Wairaki, Birchwood, Nightcaps, Gorge Road, Seaward Moss, and Otaraia-Waiarikiki districts. The increase in sheep is from 377,900 in 1960 to $1,038,000$ in 1970 and I ,6 12,800 in 1980. The comparable run cattle numbers are 30,600, 38,900, and 49,200, and dairy cattle have remained constant. The increased area in grass has been assessed at 90,000 acres.

\section{Class 3-Pastoral Land-1,405,500 Acres}

The greater area is in northern Southland and is mainly held under Crown lease. Of the total area 16 per cent is below the $1,500 \mathrm{ft}$ contour, 31 per cent is between the $1,500 \mathrm{ft}$ to $3,000 \mathrm{ft}$ ' contour, with the balance of 53 per cent at a higher altitude. There is a growing awareness among runholders, scientists, conservators, and landlord alike that soil conservation is synonymous with good management. The area of arable land $(90,000$ acres) is quite significant and the present trend of grassing should continue. About 1,000 tons of super is being applied to the pastoral lands annually, but so far very little has been put on above 1,500 ft. Sheep increases in this class indicate an annual average of 2.2 per cent over the 20 year period, but, cattle show a more encouraging trend, with a 3.3 per cent increase. An additional 30,000 acres of grass is estimated to be sown over the 20 years and aerial operations should play an important part.

\section{Class 4-Developed Land-1,500,000 Acres}

We now turn our attention to the great Southland Plains on which Southland's reputation, not to mention its wealth, has largely been built, so I trust that the owners will pardon me for suggesting that they too have a substantial unrealised potential, particularly in certain areas. The not uncommon sight of 5-6 ewes per acre with 120 per cent of lambs leaves a lasting impression of Southland at its best, but the overall average is about 3.5 ewe equivalents per grassed acre. I estimate an annual average increase in sheep at the rate of 1.2 per cent. Cattle numbers go 
up by 2.4 per cent over the full period. Farmers in the previous classes discussed will be flooding the market with store stock, so therein lies the opportunity for the fattener!

\section{Increase in Stock}

Having disposed of the fragmentation process. I would now draw your attention to the end product. 'The graphs show the trend in the various classes of stock and produce, but time will

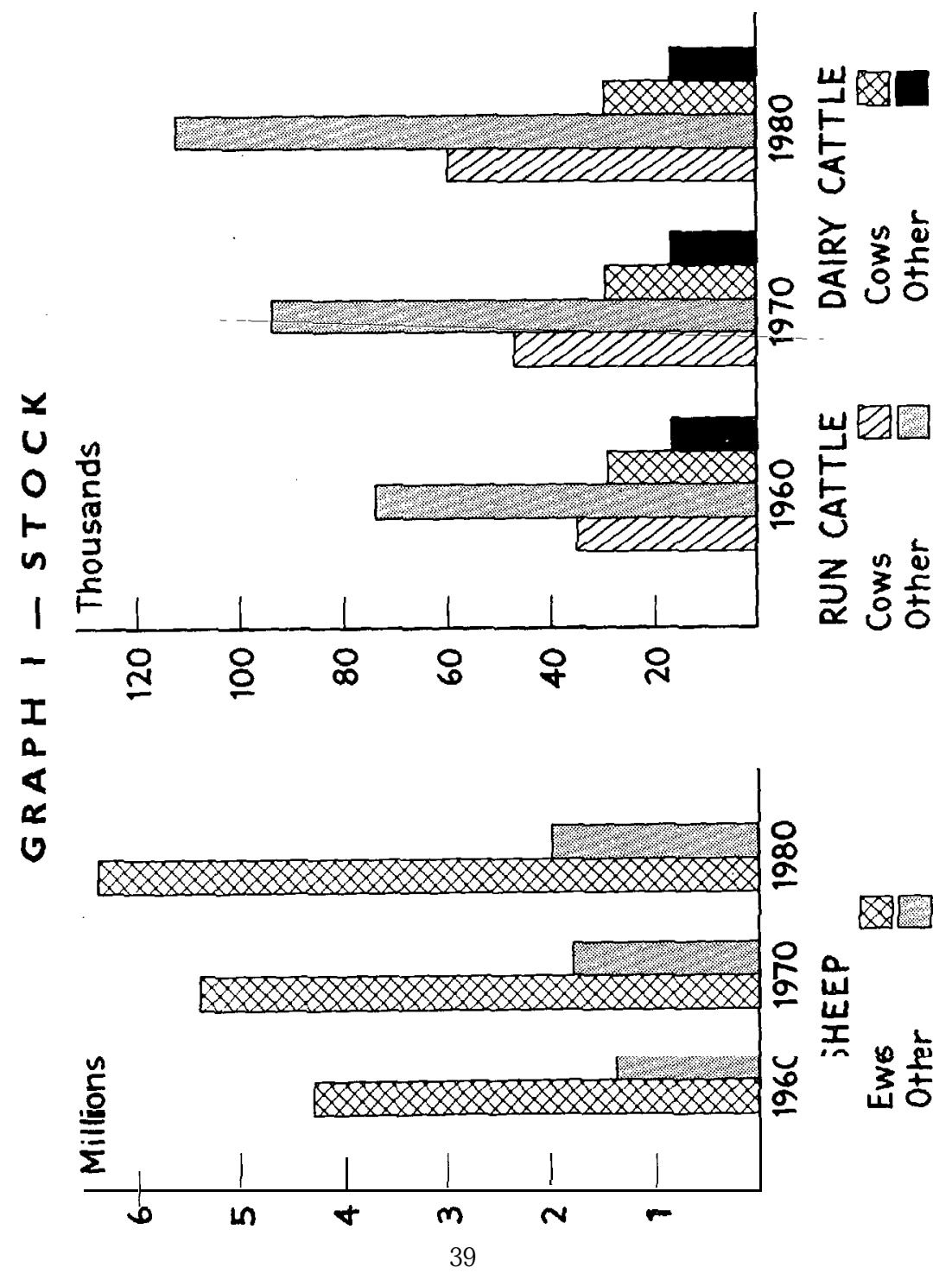


allow me only to touch briefly on the main items. Graph 1 gives the stock increase and Graph 2 deal\& with the resultant sales; all figures are shown to the nearest thousand and arc focused on the 1960, 1970, and 1980 periods.

Sheep numbers increase from $5.75 \mathrm{~m}$. to $8.45 \mathrm{~m}$., the annual average being 2.35 per cent for the 20 -year period. Total run cattle at 109,000 rise to 170,000 , this being 2.85 per cent, but it is noteworthy that run cows increase at the rate of 3.43 per cent. Today beef cattle are about as rare as the kakapo. With the greatly improved killing and handling facilities the last prop from the wall of prejudice has been removed. With the emphasis now on baby beef the aim should be to dispose of the fat stock before a second winter. This is a bold statement to make in a Hereford stronghold and, I know, not always possible of fulfilment.

Then we turn to the Cinderella of Southland, the disappearing dairy cow. I must admit that in this case the potential is unpredictable, due mainly to the human factor. After all, Southland has consistently held the South Island record for production per cow. Last season's figures, as supplied by the Herd Improvement Department of the Dairy Association, confirm this with a butterfat average of $356 \mathrm{lb}$, against a South Island average of $334 \mathrm{lb}$. There is a challenge to the younger generation, when liinited finance has to be reckoned with, to turn to dairying when bringing in virgin land. Any increase here, I am afraid, will be offset by a decrease in other places.

\section{Income}

Graph 2 will, I trust, arouse interest.

Wool sales increase from 185,000 to 276,000 bales, nearly 50 per cent over the 20 years. Sheep killings rise from $4 \mathrm{~m}$. to $6.17 \mathrm{~m}$. Prime beef cattle, 23,000 in 1960 , increase to 38,000 in 1980 , while dairy produce, excluding town supply, remains static.

The total income figures are arresting; $£ 21 \mathrm{~m}$, in 1960 tips the scales at $£ 26.5 \mathrm{~m}$. in 1970 , finishing with $£ 31.3 \mathrm{~m}$. in 1980 . And just as surely as Southland is surging into the sixties will the increased production spill over into the eighties and beyond. 1 have not dealt with cash crops or small seeds, but as is well known these commodities make, and will continue to makc, a worthwhile contribution to Southland's economy.

\section{Co-operative Effort}

This sustained and substantial increase in production can be achieved only through the combined efforts of State and private enterprise, with the greater contribution coming from the latter. Government land development should be concentrated where most 


\section{GRAPH 2 - SALES}

\section{No. of Bales}

inThousands

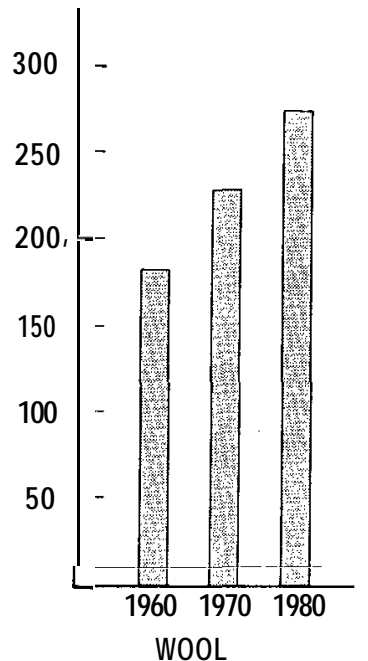

\section{No. of Carcases}

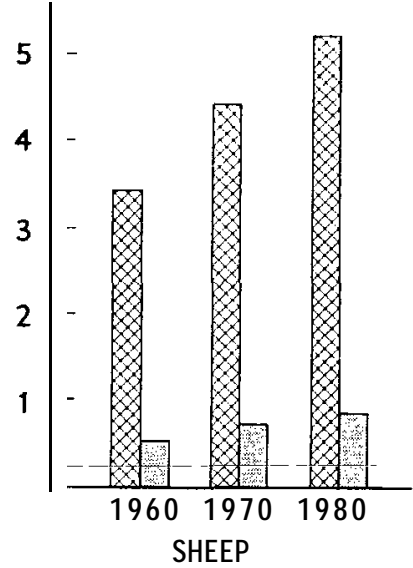

Fat lambs

Other sheep

\section{Nci. of Carcases}

in Thousands

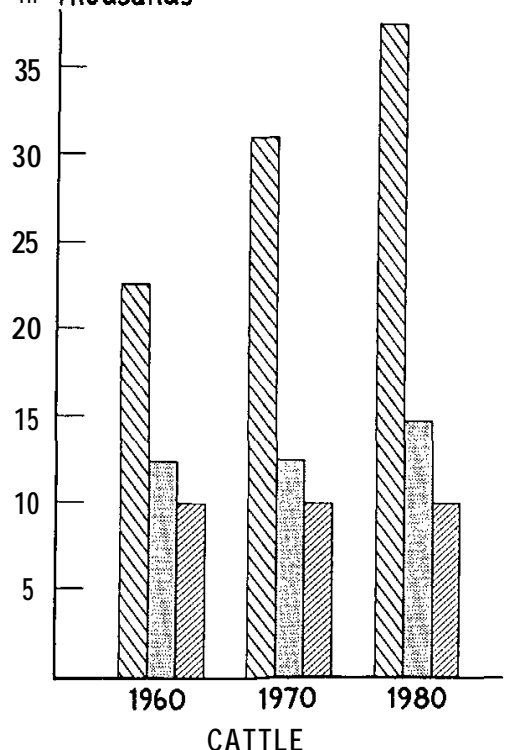

Lbs. Butterfat

in Millions

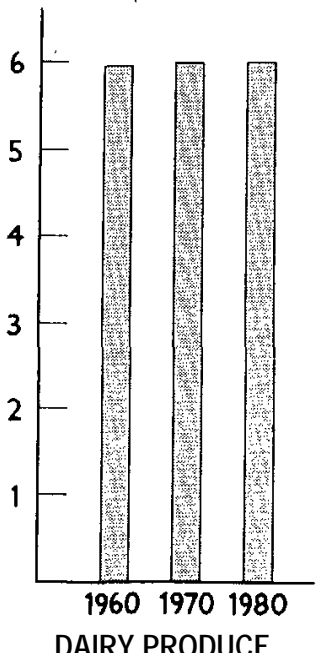

Prime \& Other

Bobby calves 


\title{
INCOME DERIVED RROM SALES
}

\author{
$£$ Million
}

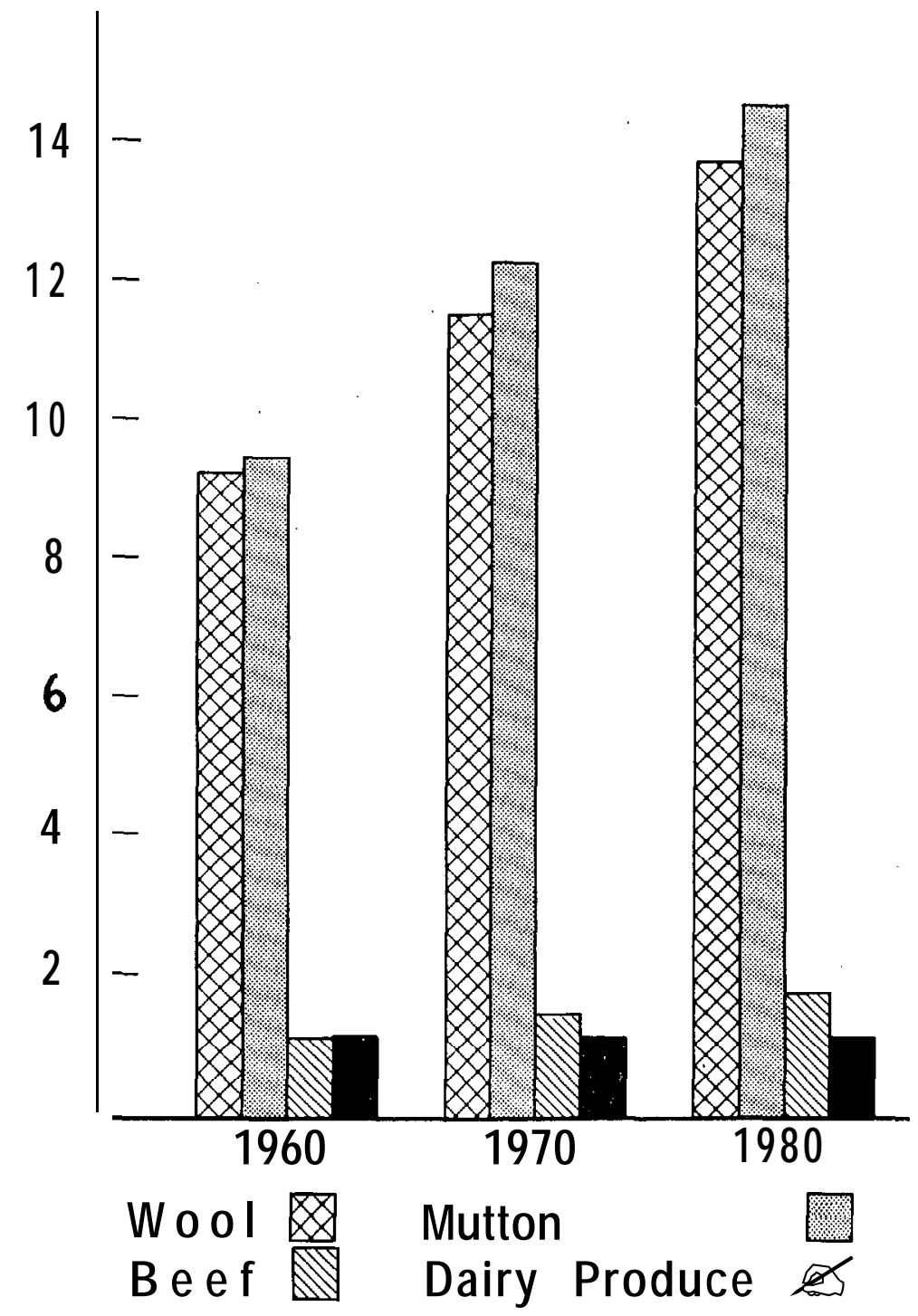




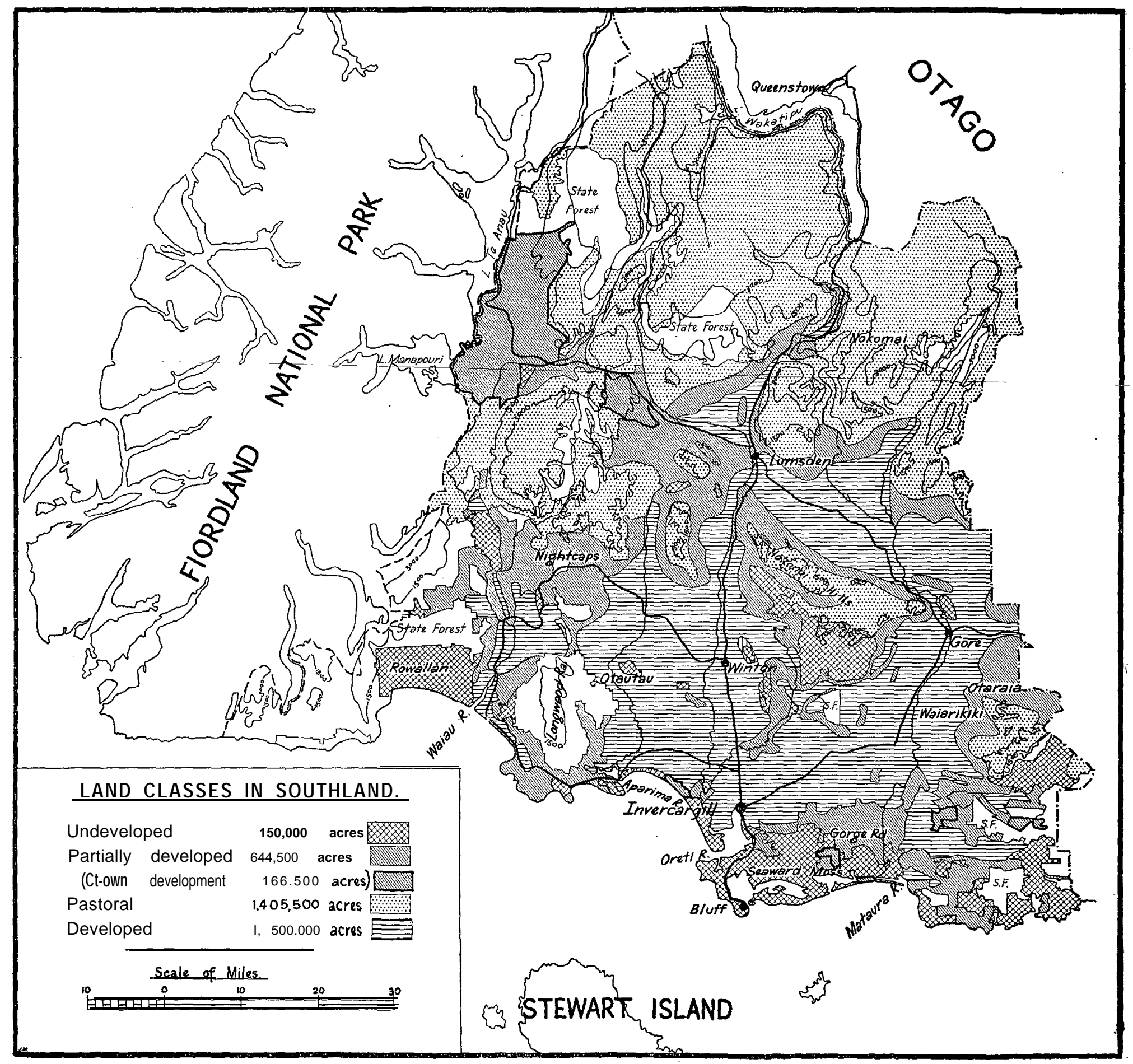


capital is needed and where returns may be slower. Let us examine the position, first in Government and then in private development.

\section{Government Land Development}

The Department of Lands and Survey's contribution to Southland development is a growing one. Southland now ranks second to Rotorua, a district which had large reserves of unoccupied Crown land. At 30 June 1960 land held in Southland totalled 166,500 acres, of which over 100,000 acres are arable and estimated to subdivide into 186 units. Of this total, 72,800 acres were acquired during the past year, so that early settlement of these unimproved areas cannot be expected.

\section{Te Anau}

The main centre of operations is around Te Anau, some 100 miles north-west_of_Invercargill. Here there are 148.000 acres of rangeland with a natural cover, mainly of fescue tussock but with considerable areas of bracken fern, and manuka varying in height and density. The arable land, 90,000 acres, rises from the shore lines of Lakes Te Anau and Manapouri (from $600 \mathrm{ft}$ to 1,500 ft). As pastoral land, the overall carrying capacity is estimated at one sheep to about six acres, but the tussock areas could be credited with one sheep to three to four acres. This should indicatc the low fertility rating of these bouldery glacial moraine and loess soils.

\section{Lynwood Farm Settlement}

Of 63,000 acres, this was the first area to be acquired (in 1953), but it has since been reduced to 39,650 acres, with 4,000 acres in bush. It was recently divided into three sub-blocks to give maximum efficiency in the handling of stock and pastures.

At the end of the present grassing season 22,000 acres of grass will have been sown and next year the final target of 23,500 acres will be reached.

Only a brief summary of the experience to date is possible here. Pastures have been established with varying degrees of success, but progress on the whole has been slower than originally thought, and as a result of more recent trials laid down by the Department of Agriculture, manurial treatment has been doubled and lime increased. It is most desirable, though not always possible, for the lime to be applied before discing and follow-up cultivation; 2 tons per acre at this stage, followed by another ton.

The aim is to sow all grass not later than November and a typical seed mixture comprises $15 \mathrm{lb}$ of ryegrass, $5 \mathrm{lb}$ of cocksfoot, $2 \mathrm{lb}$ of timothy, $3 \mathrm{lb}$ of white clover, $2 \mathrm{lb}$ of Montgomery red clover, and $2 \mathrm{lb}$ of dogstail, total $29 \mathrm{lb}$. This season clover will 


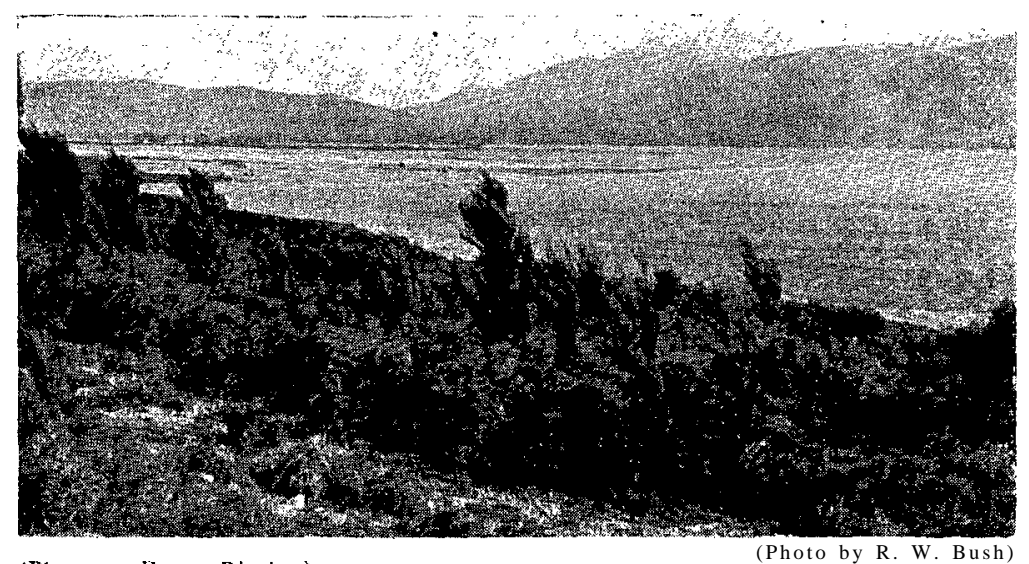

(Photo by D. R. Rinckes)

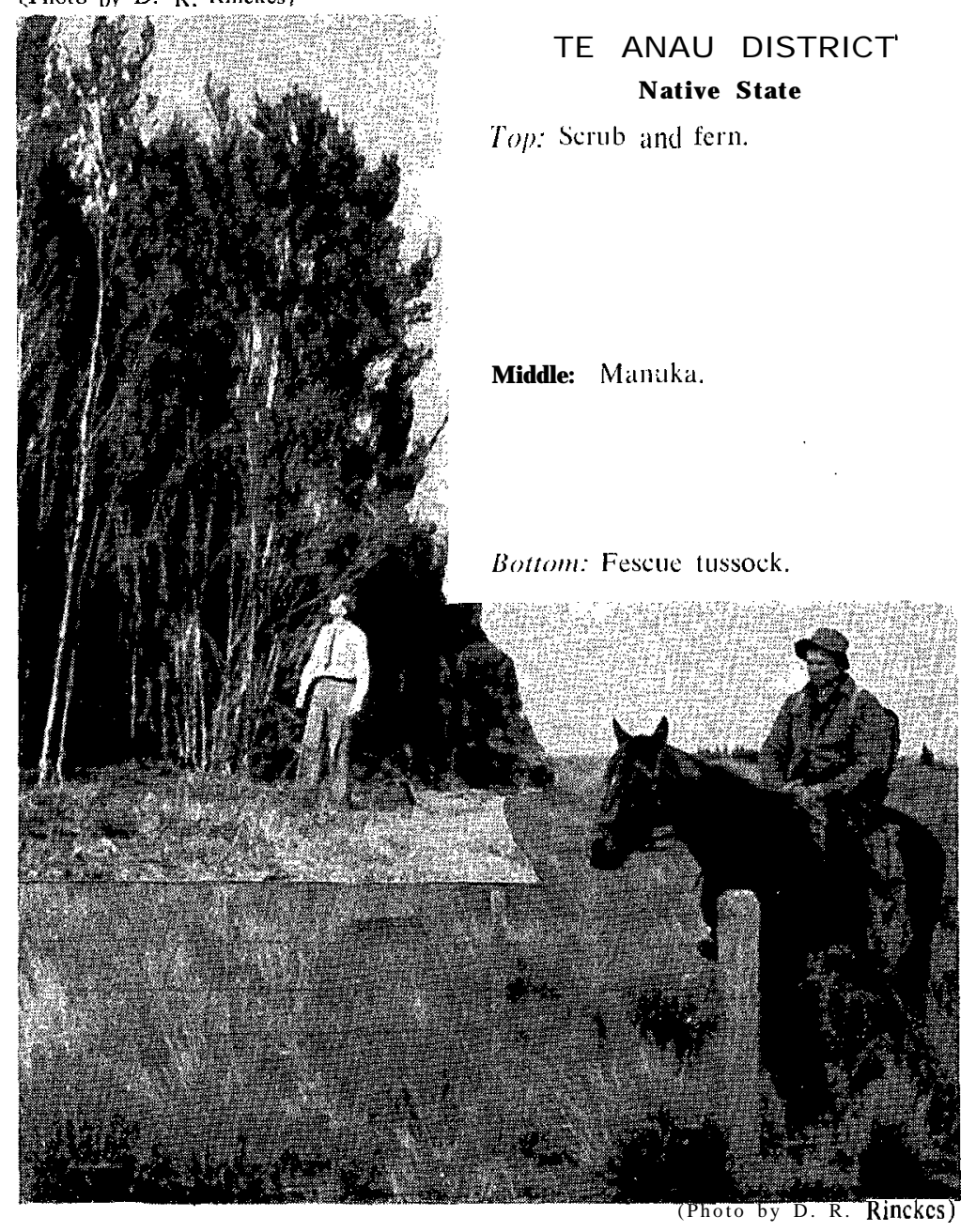




\section{DEVELOPED}

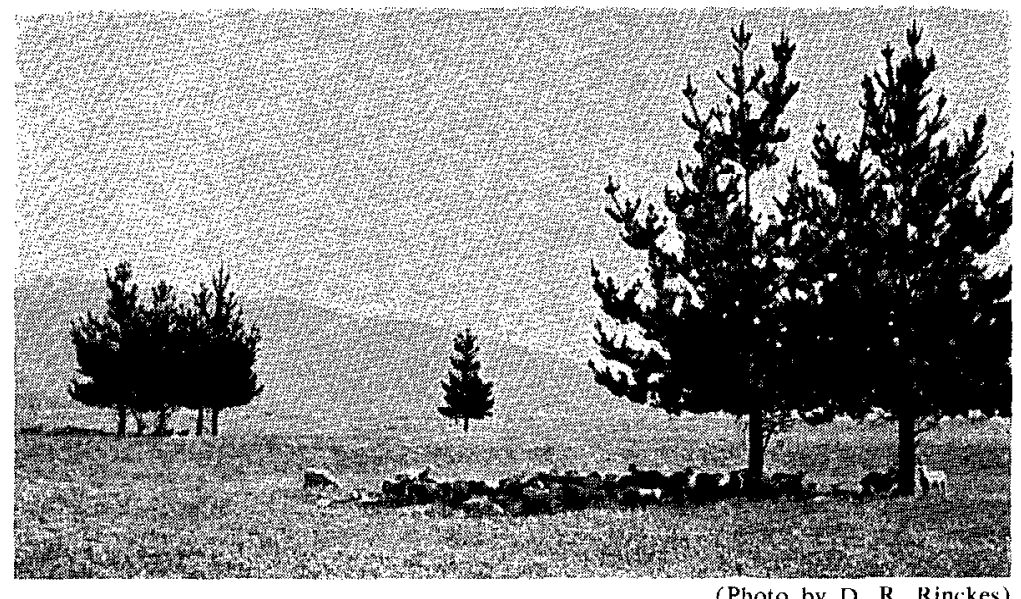

Predominantly Clover Pasture

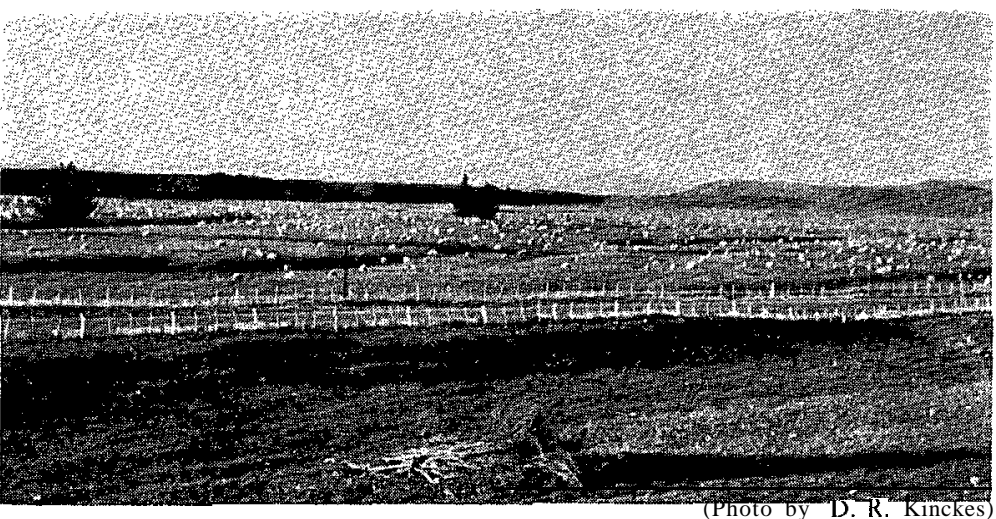

4-year Pasture

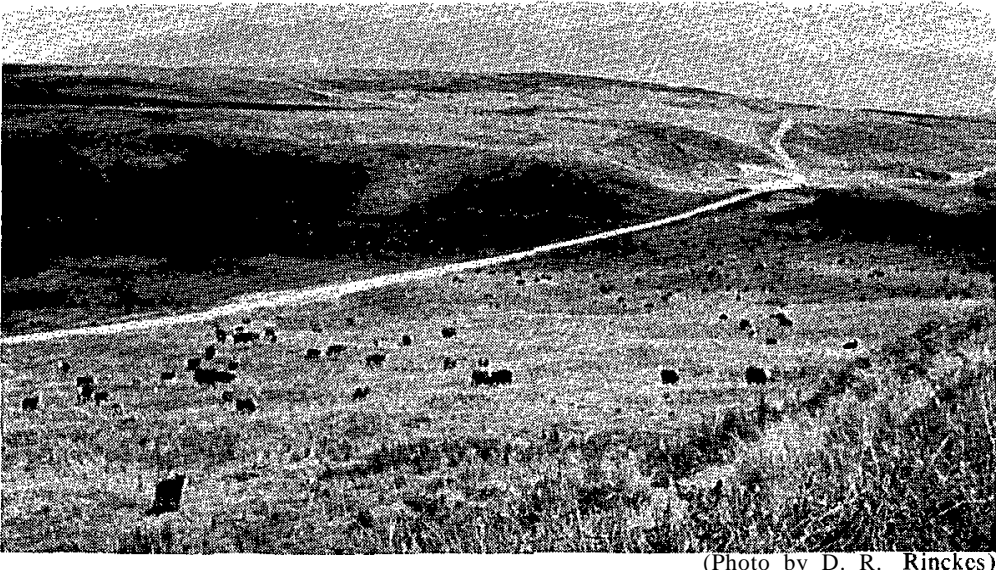

3-year Pasture 
be inoculated and pastures sown down with $4 \mathrm{cwt}$ of super phosphate per acre ( $2 \frac{1}{2} \mathrm{oz}$ molybdenum) followed by $2 \mathrm{cwt}$ of D.D.T. super in the autumn and a further $2 \mathrm{cwt}$ of super in the spring. An average soil test of 0.5 of phosphate against an optimum rating of 9 suggests a marked deficiency and possibly the position is aggravated by fixation in the soil, coupled with a retarded nitrogen cycle.

Lynwood, when taken over, was carrying 4,350 sheep and 1, 100 cattle. The present area is now running 24,000 shcep and 3,800 cattle, but it is estimated that with 22,000 acres grassed stock numbers will be increased to 32,800 sheep and 4,000 cattle next season. This represents 1.27 ewe equivalents per acre grassed plus cattle, and I submit that at least 2 ewe equivalents should be reached by settlement, otherwise the undertaking would be costly to the taxpayer and wasteful of land in that fewer sections would be available. Settlement is envisaged on the basis of 1,000 cwes and replacements, but with a good potential which can be fully realised only on the second round of grassing. Last year 4,000 wether lambs were fattened, averaging $34 \mathrm{lb}$ with 36 per cent of seconds, etc.

\section{Seaward Moss}

This is an area that cannot be overlooked, situated as it is but 17 miles south-east of Invercargill. The soil is mainly a peat complex of varying depths and in 1951 the Department undertook pioneering work in this area. Several years later the Catchment Board provided outfall drainage and now 1,400 acres of pasture have been established by the Department. The potential here is good but costly, and to date Crown as well as private development has been confined to the more favourable areas,

\section{Marginal Lands}

The administration of the Marginal Lands Act 1950 is an outstanding example of Crown and private co-operation and is, humanly speaking, a most rewarding facet of the Department's work. Since inception 76 loans have been granted to private farmers in Southland, the average loan being $£ 3,850$. Of these loans 23 farms are located within a radius of 10 miles from Invercargill, and a further 27 between a 10-20 mile radius, the majority being in the Seaward Moss area. It is significant, too, that 18 per cent of the total money advanced has been for draining, 44 per cent for clearing and grassing, the balance (38 per cent) for buildings, fencing, stock, plant, etc. Marginal Lands finance has opened the gateway to increased production, but the real secret of success lies in the innate industry and integrity of the farmer, aided by his wife. Stock firms and lending institutions 
have made a marked contribution. I am sure, too, that some of the credit is attributable to Southland's bracing climate. In the realisation of the yet untapped potential of Southland, Marginal Lands assistance must find an ever-increasing place. However, the fact that this form of rural credit is designed to finance development only where finance is unobtainable from normal sources leaves the greater proportion of privately occupied land beyond its scope. How is the potential of this land to be realised?

\section{Private Development}

I have mentioned co-operative effort. A noted statesman once said that the highest form of co-operation is the spontaneous co-operation of a free people. Through our concept of freedom, however, there runs a vein of self-interest that is by no means confined to farmers or to Southland.

My appeal is first to the older generation of farmers frankly and-freely to study their individual circumstances. In other words, the best contribution to increased production should emanate from the family hearth, In many cases there is a not unnatural tendency for parents to retain control well beyond their allotted span, while their kith and kin long for a greater measure of responsibility and ownership. Even more regrettable is the tendency for some estates to be run with indifferent results, while the younger generation is denied the incentive to increase production.

The Young Farmers' Club movement in Southland reports a membership of 1,000 and here alone is a fruitful potential. A recent survey indicates that more than 60 per cent will have insufficient finance to attain their life's ambition and of these 40 per cent desire settlement within the next five years. Federated Farmers should join with the younger generation in its wholesome zeal for progress and such an influential body has a responsibility to guide and direct this enthusiasm into the most useful channels, When, I wonder, will the Farm Improvement Club movement penetrate the deep south?

That private enterprise can make a major contribution has been demonstrated again and again. Perhaps the best known example is the performance on the Mt. Linton Station. In 1945 the late Noel McGregor started a major scheme which has been continued by his trustees. Some 8,000 acres have been brought in, partly from poor quality red tussock land, but largely from scrub and fescue tussock. Several thousand acres have been oversown and topdressed. Stock in 1945 numbered only 11,000 sheep and 350 cattle, in striking contrast to the present figures of 32,000 sheep and 2,500 cattle. The wool clip has increased five-fold. Is it any wonder that Southland, the sixth largest land district in 
New Zealand, has the fifth highest number of sheep, the fourth highest number of ewes, and the third highest number of lambs?

\section{Conclusion}

New Zealand farmers command supreme place for production per unit of labour. If the altruistic goal of full production is to be achieved and maintained, here and elsewhere, combined planning by farmer, financier, and scientist alike is essential.

I have not overlooked the contribution that the State can make and will continue to make, apart altogether from providing a buffer between the over-enthusiastic who press their claims for early settlement and the pessimistic critics who depress but satisfy themselves with the cry of "too far, too fast, and too costly". After a few years an average of at least 12 farms annually should be available for settlement.

We live in a time of world revolution on a scale hitherto unknown, an age when peoples and nations are seeking selfdetermination, inspired by a growing awareness of the dignity of man. Two-thirds of the world population is living below the breadline with implications only too well known, and over 40 million fellow human beings languish in refugee camps, awaiting the freedom that we accept as our natural heritage. New Zealand's greatest contribution to a hungry world, not to mention our own well-being, must depend largely on the exportable surplus of our primary produce. Herein lies the challenge. Knowing something of Southland's farming past and its tempo in the present, I have a healthy optimism towards its future. I have inundated you with "opinions", time alone will test the quality of their metal.

(Maps and graphs for this article supplied by Department of Lands and Survey, Invercargill.) 
TABLE 2-POTENTIAL PRODUCTION 19,60-1980

Class

1960

SHEEP

Ewes
Other

T o t a 1

RUN CATtLE

cows

Other -...

Total

DAIRY CATTLE

cows

Other.

Total

$$
\text { STock (to nearest thousand) }
$$

Nos.

4,315

1,439
5,754

35
74

109

29
17

46

$29 \quad-$

$46-$
Nos. \% Increase

Nos.

5,417

25.5

6,409

6,409
2,044

7,176

24.7

8,453

1960-1980

Annual Average

$\%$ Increase $\%$ Increase

$\begin{array}{lll}18.3 & 48.5 & 2.42\end{array}$

$\begin{array}{lll}18.3 & 48.5 & 2.42 \\ 16.2 & 42.0 & 2.10\end{array}$

$\begin{array}{rrrrrr}47 & 34.3 & 59 & 25.5 & 68.6 & 3.43 \\ 94 & 27.0 & 112 & 19.1 & 51.4 & 2.57 \\ 141 & 29.3 & -1 / 71 & 21.3 & 56.9 & 2.85\end{array}$

$-$

-

- - 
TABLE I-LAND CLASSES AND THEIR POTENTIAL

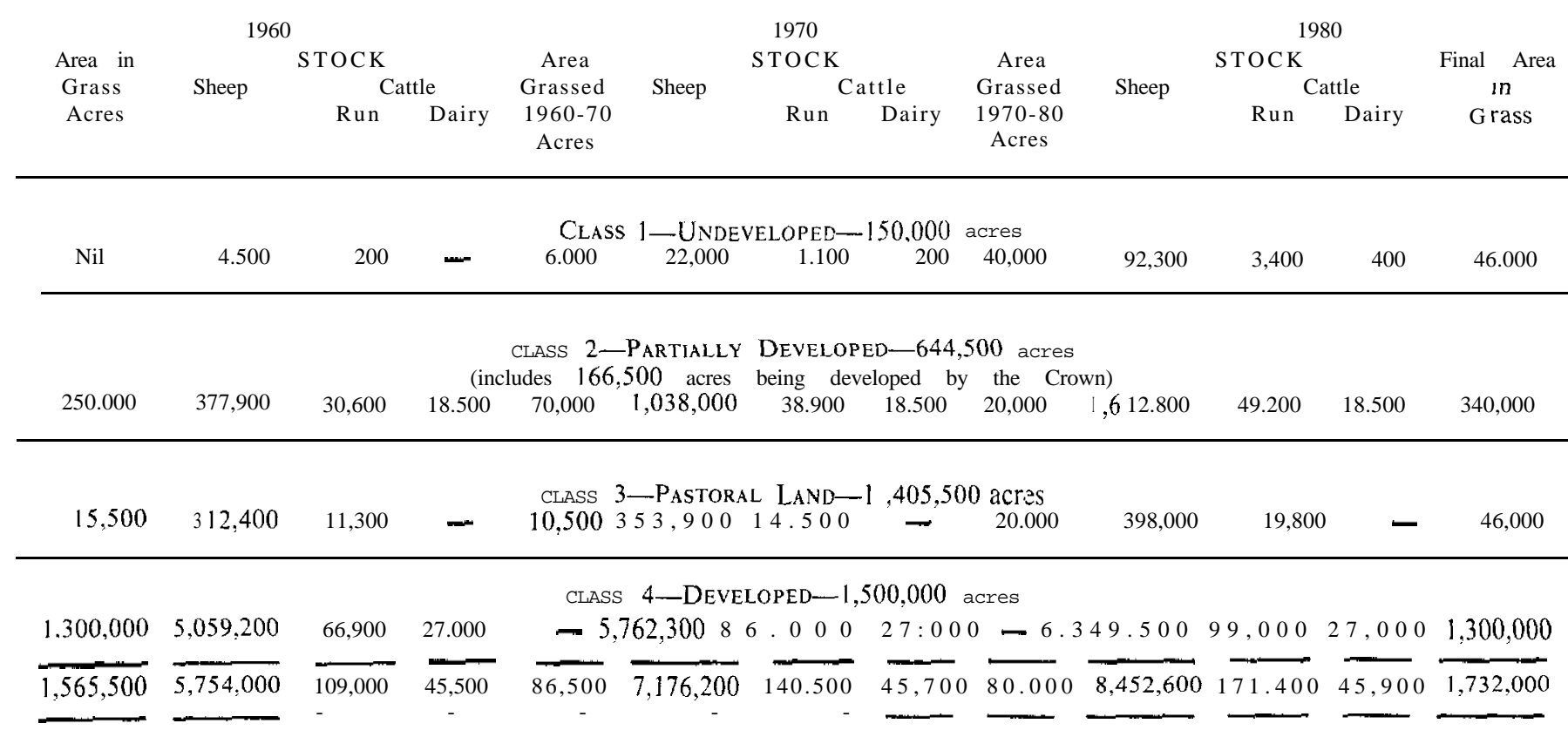




\section{I.AND DEVEIOPMENT POSSIBILITIES IN SOUTHLAND \\ DISCUSSION}

Q. If there are 12 farms available for settlement each year in the future. how many applicants will there be?

A. It is not possible to answer the question precisely but from past cxperience there should be many more applicants than farms. There is an unsatisfied demand for farms in New Zealand and as limited finance confronts so many would-be farmers State assisted settlement is vital.

Q. If the market for lamb is already near saturation, where will the extra production be sold?

A. As my paper deals with the physical aspect of production I did not attempt to assess the economic or marketing conditions. My answer is that new markets must be found.

Q. What are your 1980 production estimates based on?

A. They are based on knowledge and experiences of known potential of land classes, and are if anything conservative.

Comment (R. H. Scott): The Department of Agriculture made similar predictions of stock increases two years ago-and it was interesting to note that the two estimates were in close agreement.

Q. Will less than 2 sheep per acre carrying capacity improve the ferlility on newly developed areas?

A. Heavier concentration of stock for short periods is necessary for consolidation purposes and at the same time this should improve the fertility of the newly developed areas.

Comment (P. D. Scars): It is doubtful that the mere stock concentration will develop fertility.

Comment (Dr Kevin O'Connor): This 2 sheep per acre capacity will he carried on clover dominant pasture and therefore fertility will improve. If it was grass dominant pasture it would not. The settlement of developed land should not be too hasty and the fertility of the land should he improved before settlement.

Q. There will be some of the Lynwood block left after your detailed development programme. What will happen to it?

A. (Mr J. Hockey) : The programme described is for conventional development methods. The balance will be developed by such techniques as oversowing. About 4,000 acres have already been treated this way.

Q. (M. Stockdill): Rates of lime used appear to be high. Could less be used?

A. Five years' experience and Department of Agriculture trials indicate that the quantities used are necessary. 
TABLE 3-POTENTIAL SALES (to nearest thousand)

Class

1960

1970

1980

1960-1980

Nos.

Nos. \% Increase

Nos.

$\%$ Increase $\%$ Increase

Annual

Wool (bales) $\ldots . .185$

$231 \quad 24.9$

$\frac{276}{5,287}$

19.5

49.2

$\%$ Increase

Fat lambs
Other sheep

$\begin{array}{crr}4,469 & 29.2 & 5,287 \\ 745 & 38.2 & 881\end{array}$

18.3

2.40

Other sheep $\quad \ldots$.

5,214

30.4

6,168

18.2

$52.8 \quad 2.64$

T o t a I - $\quad 3,998$

Prime cattle

Other cattle

$\begin{array}{ll}31 & 34.8\end{array}$

23
12
10

Tótal -...

$\begin{array}{cc}1 & 3 \\ 1 & 10\end{array}$

8.3

18.3

63.4

3.17

\begin{tabular}{ll} 
Butterfat (Ib) & 45 \\
\{Town Supply excluded) & 6,000 \\
\hline
\end{tabular}

Total Income $£ 21,042,000$

$\begin{array}{ll}54 & 20.0\end{array}$

6,025

$£ 26,526,000$

$26.1 \quad\{31,341,000$

$\begin{array}{lll}22.6 & 65.2 & 3.26\end{array}$

$\begin{array}{rrr}22.6 & 65.2 & 3.26 \\ 15.4 & 25.0 & 1.25 \\ - & - & -\end{array}$

$\begin{array}{lll}16.7 & 40.0 & 2.00\end{array}$

18.2

48.9 